\title{
STUDY OF RADIOACTIVITY IN ENVIRONMENT AROUND POWER PLANTS TENT A AND KOLUBARA DUE TO COAL BURNING FOR 2015
}

\author{
Marija M. Jankovié1 ${ }^{*}$, Milica M. Rajačić1 ${ }^{1}$ Dragana J. Todorović1, Nataša B. Sarap ${ }^{1}$, \\ Jelena D. Nikolić ${ }^{1}$, Gordana K. Pantelić́ ${ }^{1}$ Milanka M. Krstiće ${ }^{2}$
}

\author{
${ }^{1}$ University of Belgrade, Vinča Institute of Nuclear Sciences, Radiation and Environmental Protection Department, \\ Belgrade, Serbia \\ ${ }^{2}$ University of East Sarajevo, Faculty of Pedagogy, Bijeljina, Bosnia and Herzegovina
}

\begin{abstract}
The results referring to radioactivity analysis in soil, water, plant, coal, slag and flying ash samples from the environment around two power plants "Nikola Tesla A" and "Kolubara" for 2015 are explained. The analysis of samples was performed by gamma spectrometry using HPGe detector. In the investigated soil, flying ash, slag and

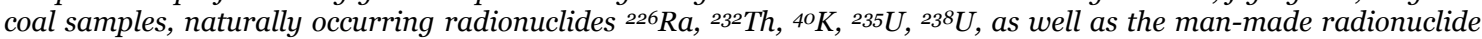

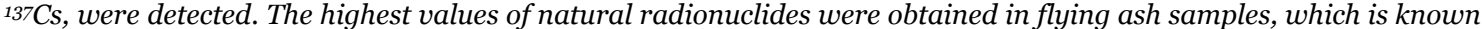
for the effect of concentrating the combustion of coal. In plant samples, beside these radionuclides, ${ }^{210} \mathrm{~Pb}$ and $7 \mathrm{Be}$ were

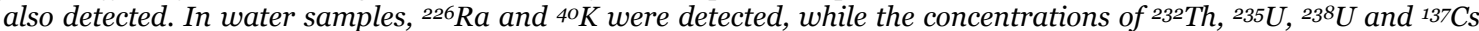
were below the minimum detectable concentration. In water (river, drinking, drain and overflow) samples, beside the gamma spectrometry analysis, gross alpha and gross beta activity was also determined. The obtained values for gross alpha and beta activity in these water samples are in accordance with the current legislation in Serbia (Official Gazette 86/11), which refers only to drinking water. The results presented in this paper showed that there was no significant difference in the activity of radionuclides in all investigated samples compared to the values obtained in previous years.
\end{abstract}

Key words: Radioactivity, environment, power plants

DOI: $10.21175 / \operatorname{RadProc} .2016 .20$

\section{INTRODUCTION}

With the advances in industrial development and human living standards, the demand for electricity throughout the world is increase [1]. The importance of studying the environmental impact of the coal fired power plants is shown by the high number of publications found in the literature during the last decade [2]-[13].

Coal, the most abundant natural resource and fossil fuel, plays an important role in electricity generation, and approximately $27 \%$ of the world's energy consumption originates from the incineration of coal. Coal combustion, the main anthropogenic source of toxic air pollution and a large contributor to global warming and acid rain, will generate a lot of pollutants, such as particulates, oxides of sulfur, nitrogen and carbon, and toxic metals like arsenic, mercury, etc., in trace concentrations [2]. Coal, like most materials found in nature, contains the natural radionuclides ${ }^{226} \mathrm{Ra},{ }^{232} \mathrm{Th}$ and ${ }^{40} \mathrm{~K}$. In the process of coal combustion, the burn-out of all combustible matter results in an increase of the natural radionuclide.

Bottom ash and fly ash are the main solid waste of coal combustion in coal fired power plants. Bottom ash

(slag) is the coarse grained materials collected at the bottom of the boiler, whereas fly ash, the fine sized particles ranging from 0.5 to $200 \mu \mathrm{m}$, is entrained in the gas stream and carried up the stack. Fly ash particles have a greater tendency to absorb trace elements (such as $\mathrm{Cu}, \mathrm{Pb}, \mathrm{Zn}, \mathrm{Cr}, \mathrm{U}$, Th, and so on) during combustion due to their relatively small size and large surface area [1].

Fly ash is released into the atmosphere and deposited on the soil around the coal fired power plants. Thus, coal combustion may enhance environmental radioactivity levels in the vicinity of the coal fired power plants due to fly ash with higher radionuclides concentrations released into the surrounding environment, which can cause radiation exposures to the public living and working in the immediate vicinity of the power plants. Coal fired power plants in Serbia are located in populated areas, hence, the environmental impact experienced by the neighboring population is significant. The radioactivity monitoring in the "Nikola Tesla", "Kolubara", "Morava" and "Kostolac" coal-fired power plants was performed by the Radiation and Environmental Protection Department, Vinča Institute of Nuclear Sciences in the period 2003-2015. Monitoring included the analysis of soil, water, flying ash, slag, coal and plants. Therefore,

marijam@vinca.rs 
to investigate the natural radioactivity levels in soil around power plants, as well as in plants and water, and to assess the associated radiation hazard is becoming an emerging and interesting topic.

\section{MATERIALS AND METHODS}

As part of monitoring in the vicinity of coal fired power plants, each performed examination by the emission of pollutants. Beside this monitoring there is a control program of radioactivity in living and working environment, which includes measurement of the ambient dose rate of gamma radiation, spectrometry of gamma emitters and measurement of gross alpha and gross beta activity. Coal-fired power plant Nikola Tesla A (TENT) is the biggest power plant in Serbia, consisting of six units with total installed power of 1,650 MW. Built on the right bank of the Sava River, near Obrenovac, it is the biggest individual producer of electric power in Serbian electric power system. At the average, more than 8 billion kilowatt hours are produced per year.

Kolubara power plant (TEK) was built in the immediate vicinity of the surface mines with the same name, from where it is supplied with coal. It is the oldest active plant in the system of the Electric Power Distribution of Serbia. With its five unit's, with total installed power of $270 \mathrm{MW}$, at that time it was the largest power facility in the country. It was commissioned in 1956, namely its two turbo aggregates of 32 MW. In 1960, it was enhanced by additional 65 MW, and already a year later, in 1961, another 32 MW turbo aggregates was commissioned. The power of this plant was then increased to the total of $161 \mathrm{MW}$. Within the limits of the existing power plant, a new $110 \mathrm{MW}$ plant was commissioned in 1979.

These coal-fired power plants use the same type of coal, lignite.

As stated in the abstract, monitoring of radioactivity in the vicinity of power plants included the analysis of soil, water, flying ash, slag, coal and plants. Here, the results referring to radioactivity analysis in these samples, which were collected near the power plants and away from it are explained.

In 2015 year the mentioned samples were collected from various sites in the vicinity of power plants.

For gamma spectrometry measurements, after removing the stones and vegetation, all soil samples were dried up to $105^{\circ} \mathrm{C}$, sieved, and placed in the plastic $500 \mathrm{~mL}$ Marinelli beakers. Coal, slag and ash samples were dried up to $105^{\circ} \mathrm{C}$, sieved and placed in appropriate measurement geometry.

Plant samples were taken from all the points where the soil samples were collected, including landfill banks and landfill plateau. Because of the great diversity of plants in the field, samples were taken randomly, because there is no possibility of taking small amounts of plants. All parts of the plant were taken in bulk, and different species of plants were native to the sampling point were collected. Plant samples were taken from the soil near landfill and from the soil away from landfill as well as from active and passive pond. For gamma spectrometry measurements, plant samples were dried at room temperature during few days, ashed at $450{ }^{\circ} \mathrm{C}$ and placed in the plastic boxes of $100 \mathrm{~cm}^{3}$.
Plants were prepared as whole, parts such as tree, root or leaf were not separated.

In the vicinity of coal fired power plants, river water samples were taken at two sites: upstream and downstream from the power plant. Also, from all investigated power plants, drain water as well as overflow water was collected. For gamma spectrometric measurement volume of about $15 \mathrm{l}$ was evaporated to a small volume, under infrared lamp. The remaining was heated to dryness at $450^{\circ} \mathrm{C}$ and the residues were transferred to a plastic box of $100 \mathrm{~cm}^{3}$.

For gamma measurements all samples are left for four weeks to reach radioactive equilibrium. Gamma spectrometric measurements were performed using a HPGe Canberra detectors with a relative efficiencies of $18 \%, 20 \%$ and $50 \%$, resolution of all of the detectors was $1.8 \mathrm{keV}$ at $1332 \mathrm{keV}$. Counting time interval was 60 ooo s and longer. The spectra were analyzed using the program GENIE 2000. The activity of ${ }^{226} \mathrm{Ra}$ and ${ }^{232} \mathrm{Th}$ was determined by their decay products: ${ }^{214} \mathrm{Bi}$ (609 $\mathrm{keV}, 1120 \mathrm{keV}$ and also $1764 \mathrm{keV}),{ }^{214} \mathrm{~Pb}(295 \mathrm{keV}$ and $352 \mathrm{keV}$ ) and ${ }^{228} \mathrm{Ac}(338 \mathrm{keV}$ and $911 \mathrm{keV})$, respectively. ${ }^{235 \mathrm{U}}$ was determined via $186 \mathrm{keV}$ corrected for ${ }^{226} \mathrm{Ra}$. ${ }^{238} \mathrm{U}$ was determined via ${ }^{234} \mathrm{Th}(63 \mathrm{keV})$ or by ${ }^{234 \mathrm{mPa}}$ (1001 keV). The activities of ${ }^{4} \mathrm{~K},{ }^{137} \mathrm{Cs}{ }^{210} \mathrm{~Pb}$ and $7 \mathrm{Be}$ were determined from its $1460 \mathrm{keV}, 661 \mathrm{keV}, 46 \mathrm{keV}$ and $477 \mathrm{keV} \gamma$-energy, respectively. The background spectrum was recorded regularly before the sample counting, with empty $200 \mathrm{~mL}$ cylindrical polyethylene bottle, $100 \mathrm{~cm}^{3}$ plastic box and $500 \mathrm{~mL}$ plastic Marinelli beaker.

For measurement of the gross alpha and beta activities in water samples, volume of $3 \mathrm{l}$ was evaporated to a small volume, under infrared lamp. The remaining was heated to dryness at $450^{\circ} \mathrm{C}$. The residues were transferred quantitatively to a stainless steel planchet. Measurements were performed immediately after preparation. The counting time was $3600 \mathrm{~s}$ for gross alpha and beta activities.

Gross alpha and beta activity was determined by $\alpha / \beta$ low level proportional counter Thermo Eberline FHT $770 \mathrm{~T}$. The counting gas was a mixture of $90 \%$ argon and $10 \%$ methane. The average counting efficiencies for the system are $23 \%$ for alpha and $33 \%$ for beta.

\section{RESULTS AND DISCUSSION}

In the samples of coal, slag and ash, the natural (226 Ra, $\left.{ }^{232} \mathrm{Th},{ }^{40} \mathrm{~K}, 235 \mathrm{U},{ }^{238} \mathrm{U},{ }^{210} \mathrm{~Pb}\right)$ and artificial $\left({ }^{137 \mathrm{Cs})}\right.$ radionuclides were detected. In plant samples beside above mention radionuclides, cosmogenic radionuclide 7 Be was also detected.

The obtained values in the analyzed samples are presented in Table 1-5. The combined uncertainty of the results, originating from counting uncertainty, measuring of sample mass and uncertainty arising from fitting of the efficiency calibration curve, was estimated to range from $4 \%$ to $40 \%$.

The concentrations of natural radionuclides in coal and slag are lower compared to the concentrations found in ash, i.e., maximum concentrations were obtained in flying ash samples (Table 1). According to UNSCEAR [14], the mean natural radionuclide concentration expected in coal is $35 \mathrm{~Bq} \mathrm{~kg}^{-1}$ (range: $17-$ 
6o) for ${ }^{226} \mathrm{Ra}, 30 \mathrm{~Bq} \mathrm{~kg}{ }^{-1}$ (range: $11-64$ ) for ${ }^{232} \mathrm{Th}$ and $400 \mathrm{~Bq} \mathrm{~kg}^{-1}$ (range: $140-850$ ) for ${ }^{\circ 0} \mathrm{~K}$. As one sees from Table 1, the radionuclide concentrations in coal samples from the Serbian power plants are in the range of coal reported in UNSCEAR.

There is a difference between the obtained values in ash samples taken from active and passive pond. For TEK all values except for ${ }^{40} \mathrm{~K}$ are higher for ash from active pond. For TENT, concentrations of radionuclides in ash from passive and active ash pond are negligible and do not exceed the statistical variance, except for ${ }^{40} \mathrm{~K}$, which value is higher for ash from active pond (Table 2).

For period 2003-2010 radioactivity concentrations in coal, slag and ash samples can be found in reference [3].

Table 3 presents the values obtained for soil samples. There is no significant difference between the soil samples taken near and far away from landfill. According to UNSCEAR [14], the current worldwide average values for concentration in soil are $32 \mathrm{~Bq} \mathrm{~kg}^{-1}$ for ${ }^{226} \mathrm{Ra}, 45 \mathrm{~Bq} \mathrm{~kg}^{-1}$ for ${ }^{232} \mathrm{Th}, 412 \mathrm{~Bq} \mathrm{~kg}^{-1}$ for ${ }^{40} \mathrm{~K}$ and $33 \mathrm{~Bq} \mathrm{~kg}^{-1}$ for ${ }^{238} \mathrm{U}$. The activity concentrations of these radionuclides obtained for soil sample in coal fired power plants in Serbia are in agreement with worldwide average concentration for soil samples, as well as with concentration in soil samples taken in Serbia from the area which is not related to power plants, and published by various authors [15]-[18].

For example, values of radioactivity concentrations in soil samples taken from these two power plants obtained for period 2003-2012 were: ${ }^{226} \mathrm{Ra}: 36 \mathrm{~Bq} \mathrm{~kg}^{-1}$, 232Th: $36 \mathrm{~Bq} \mathrm{~kg}^{-1},{ }^{40} \mathrm{~K}: 490 \mathrm{~Bq} \mathrm{~kg}{ }^{-1},{ }^{23}{ }^{8} \mathrm{U}: 41 \mathrm{~Bq} \mathrm{~kg}^{-1}$, 235U: $2.3 \mathrm{~Bq} \mathrm{~kg}-1,{ }^{137} \mathrm{Cs}: 42 \mathrm{~Bq} \mathrm{~kg}^{-1}$, for TENT, and ${ }^{226} \mathrm{Ra}$ : $49 \mathrm{~Bq} \mathrm{~kg}-1,{ }^{232} \mathrm{Th}: 52 \mathrm{~Bq} \mathrm{~kg}^{-1},{ }^{0} \mathrm{~K}: 525 \mathrm{~Bq} \mathrm{~kg}^{-1},{ }^{23} 8 \mathrm{U}: 54$ $\mathrm{Bq} \mathrm{kg}{ }^{-1},{ }^{235 \mathrm{U}:} 2.5 \mathrm{~Bq} \mathrm{~kg}^{-1},{ }^{137 \mathrm{Cs}:} 24 \mathrm{~Bq} \mathrm{~kg}^{-1}$, for TEK [2].

Plant samples were taken from a flat part of passive pond, from a causeway of passive pond and from a causeway of active pond. For TEK, the highest value of ${ }^{226} \mathrm{Ra}$ was obtained for plant from a causeway of passive pond, ${ }^{232} \mathrm{Th}$ and ${ }^{40} \mathrm{~K}$ were the highest for plant from a flat part of passive pond, ${ }^{137} \mathrm{Cs}$ and ${ }^{210} \mathrm{~Pb}$ were the highest for plant from a causeway of active pond. For TENT, ${ }^{226} \mathrm{Ra},{ }^{232} \mathrm{Th},{ }^{4} \mathrm{~K}$ and ${ }^{137} \mathrm{Cs}$ were the highest for plant from a causeway of passive pond, ${ }^{238} \mathrm{U}$ and ${ }^{210} \mathrm{~Pb}$ were the highest for plant from a flat part of passive pond and ${ }^{235} \mathrm{U}$ was the highest for plant from a causeway of active pond (Table 4).

Plant samples were also taken near and far away from landfill (Table 5). For TEK, all detected radionuclides were higher for samples away from landfill, except ${ }^{210} \mathrm{~Pb}$. For TENT ${ }^{226} \mathrm{Ra},{ }^{4} \mathrm{~K}$ and ${ }^{137 \mathrm{Cs}}$ were higher for samples taken near the landfill, except ${ }^{232} \mathrm{Th}$ and ${ }^{210} \mathrm{~Pb}$.

For example, values of radioactivity concentrations in plant samples taken from these two power plants obtained for period 2003-2012 were: ${ }^{226} \mathrm{Ra}: 5.2 \mathrm{~Bq} \mathrm{~kg}^{-1}$, 232Th: $1.7 \mathrm{~Bq} \mathrm{~kg}^{-1},{ }^{0} \mathrm{~K}: 505 \mathrm{~Bq} \mathrm{~kg}^{-1},{ }^{210} \mathrm{~Pb}: 25 \mathrm{~Bq} \mathrm{~kg}^{-1}$, for TENT, and ${ }^{226} \mathrm{Ra}: 4.8 \mathrm{~Bq} \mathrm{~kg}^{-1},{ }^{232} \mathrm{Th}: 3.2 \mathrm{~Bq} \mathrm{~kg}^{-1},{ }^{\circ} \mathrm{K}$ : $534 \mathrm{~Bq} \mathrm{~kg}^{-1},{ }^{23} 8 \mathrm{U}: 4.9 \mathrm{~Bq} \mathrm{~kg}^{-1}$, and ${ }^{210} \mathrm{~Pb}: 47 \mathrm{~Bq} \mathrm{~kg}^{-1}$, for TEK [2].

As already mentioned, in the vicinity of coal fired power plants, river water samples were taken at two sites: upstream and downstream from the power plant. Also, from all investigated power plants, drain water as well as overflow water was analyzed. Using gamma spectrometry analysis, natural radionuclides ${ }^{226} \mathrm{Ra},{ }^{\circ} \mathrm{K}$ and ${ }^{210} \mathrm{~Pb}$ were detected in water samples (Table 6). Concentrations of radionuclides ${ }^{232} \mathrm{Th},{ }^{137} \mathrm{Cs},{ }^{235 \mathrm{U}},{ }^{238} \mathrm{U}$ were below the MDC.

In all investigated water samples, beside gamma spectrometry, gross alpha and gross beta activity was determined. The obtained results are presented in Table 7. Gross alpha activity in all samples for the whole investigation period was below the MDC, except for overflow water from TENT where detected gross alpha activity was $0.11 \mathrm{~Bq} \mathrm{l}^{-1}$. On the other hand, obtained values for gross beta activity in these water samples were in the range $<0.08-0.6 \mathrm{~Bq} \mathrm{l}^{-1}$, and are in accordance with current legislation [19]. Similar values were obtained for water samples for period 2003-2012 [2]. In Serbia, according to current regulations [19], radioactivity concentrations in drinking water for gross alpha and gross beta should not exceed 0.5 and 1.0 Bq $\mathrm{l}^{-1}$, respectively. One investigated water from TEK was drinking water and obtained values were: for gross

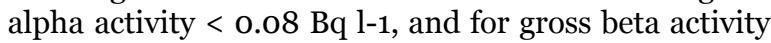
$<0.09 \mathrm{~Bq} \mathrm{l}^{-1}$. Other waters investigated in this paper are not drinking water, but obtained values in analyzed samples for the gross alpha and beta activity are the same as in drinking water. For example in drinking mineral waters as well as in tap and spring water from Serbia, gross alpha and beta activity are within the recommended values of 0.5 and $1.0 \mathrm{~Bq} \mathrm{l}^{-1}$ [20], [21].

Table 8 contains values for radioactivity concentrations in soil samples taken around coal fired power plants in different countries, as well as in Serbia but for soil samples taken in the city near power plant and also for soil samples taken from areas that are not related to power plants.

Table 1. Radionuclides (Bq kg-1) in coal, slag and flying ash samples from TEK and TENT

\begin{tabular}{|c|c|c|c|c|c|c|}
\hline Sample & \multicolumn{2}{|c|}{ Coal } & \multicolumn{2}{c|}{ Slag } & \multicolumn{2}{c|}{ Fying ash } \\
\hline $\begin{array}{c}\text { Power } \\
\text { plant }\end{array}$ & IEK & IENT & IEK & IENT & IEK & TENT \\
\hline${ }^{226} \mathrm{Ra}$ & $32 \pm 2$ & $37 \pm 3$ & $24 \pm 2$ & $96 \pm 7$ & $140 \pm 10$ & $40 \pm 3$ \\
\hline${ }^{232} \mathrm{Th}$ & $22 \pm 2$ & $29 \pm 3$ & $17 \pm 2$ & $57 \pm 5$ & $104 \pm 7$ & $30 \pm 2$ \\
\hline${ }^{40} \mathrm{~K}$ & $100 \pm 10$ & $190 \pm 10$ & $170 \pm 10$ & $210 \pm 20$ & $520 \pm 30$ & $300 \pm 20$ \\
\hline${ }^{137} \mathrm{Cs}$ & $<0.2$ & $<0.2$ & $<0.1$ & $<0.3$ & $<0.3$ & $<0.1$ \\
\hline${ }^{238} \mathrm{U}$ & $30 \pm 4$ & $52 \pm 5$ & $20 \pm 3$ & $100 \pm 10$ & $150 \pm 10$ & $50 \pm 5$ \\
\hline${ }^{235} \mathrm{U}$ & $1.7 \pm 0.1$ & $2.6 \pm 0.3$ & $1.0 \pm 0.1$ & $3.8 \pm 0.3$ & $8.0 \pm 0.6$ & $2.2 \pm 0.2$ \\
\hline${ }^{210} \mathrm{Ph}$ & $32 \pm 4$ & $40 \pm 4$ & $19 \pm 3$ & $35 \pm 6$ & $120 \pm 10$ & $34 \pm 4$ \\
\hline
\end{tabular}


Table 2. Radionuclides (Bq kg-1) in flying ash samples taken from active and passive pond from TEK and TENT

\begin{tabular}{|c|c|c|c|c|}
\hline Sample & \multicolumn{2}{|c|}{ Ash active pond } & \multicolumn{2}{l|}{ Ash pasive pond } \\
\hline $\begin{array}{c}\text { Power } \\
\text { plant }\end{array}$ & IEK & IENT & IEK & IENT \\
\hline${ }^{226}$ Ra & $144 \pm 9$ & $82 \pm 8$ & $115 \pm 8$ & $84 \pm 7$ \\
\hline${ }^{232}$ Th & $97 \pm 7$ & $60 \pm 6$ & $95 \pm 7$ & $58 \pm 5$ \\
\hline${ }^{40} K$ & $350 \pm 20$ & $510 \pm 40$ & $520 \pm 30$ & $360 \pm 30$ \\
\hline${ }^{137} \mathrm{Cs}$ & $<0.2$ & $<0.3$ & $<0.2$ & $<0.3$ \\
\hline${ }^{238} \mathrm{U}$ & $160 \pm 10$ & $80 \pm 10$ & $110 \pm 10$ & $85 \pm 9$ \\
\hline${ }^{235} \mathrm{U}$ & $8.4 \pm 0.6$ & $3.9 \pm 0.5$ & $5.0 \pm 0.4$ & $4.2 \pm 0.4$ \\
\hline${ }^{210} \mathrm{Ph}$ & $120 \pm 10$ & $50 \pm 10$ & $80 \pm 8$ & $45 \pm 8$ \\
\hline
\end{tabular}

Table 3. Radionuclides (Bq kg-1) in soil samples taken near and far away from landfill from TEK and TENT

\begin{tabular}{|c|c|c|c|c|}
\hline Sample & \multicolumn{2}{|c|}{ Soil near the landfill } & \multicolumn{2}{|c|}{ Soil awry from landfill } \\
\hline $\begin{array}{c}\text { Power } \\
\text { plant }\end{array}$ & IEK & IENT & IEK & IENT \\
\hline${ }^{226} \mathrm{Ra}$ & $48 \pm 3$ & $26 \pm 3$ & $44 \pm 3$ & $29 \pm 3$ \\
\hline${ }^{232} \mathrm{Th}$ & $58 \pm 4$ & $30 \pm 3$ & $55 \pm 4$ & $33 \pm 3$ \\
\hline${ }^{40} \mathrm{~K}$ & $680 \pm 40$ & $410 \pm 30$ & $510 \pm 30$ & $470 \pm 30$ \\
\hline${ }^{137} \mathrm{Cs}$ & $<0.1$ & $14 \pm 1$ & $24 \pm 1$ & $11 \pm 1$ \\
\hline${ }^{238} \mathrm{U}$ & $45 \pm 5$ & $29 \pm 7$ & $50 \pm 6$ & $33 \pm 7$ \\
\hline${ }^{235} \mathrm{U}$ & $2.1 \pm 0.2$ & $1.8 \pm 0.2$ & $2.4 \pm 0.2$ & $1.5 \pm 0.2$ \\
\hline${ }^{210} \mathrm{~Pb}$ & $26 \pm 5$ & $29 \pm 4$ & $56 \pm 5$ & $34 \pm 8$ \\
\hline
\end{tabular}

Table 4. Radionuclides $\left(\mathrm{Bq} \mathrm{kg}^{-1}\right)$ in plant samples taken from active and passive pond from TEK and TENT

\begin{tabular}{|c|c|c|c|c|c|c|}
\hline Sample & $\begin{array}{c}\text { Plant from a flat part of } \\
\text { passive pond }\end{array}$ & \multicolumn{2}{|c|}{\begin{tabular}{c}
\multicolumn{2}{|c|}{ of pant from a causewry } \\
of pant from a causewry \\
of active pond
\end{tabular}} \\
\hline $\begin{array}{c}\text { Power } \\
\text { plant }\end{array}$ & IEK & IENT & IEK & IENT & IEK & IENT \\
\hline${ }^{226}$ Ra & $0.7 \pm 0.2$ & $3.3 \pm 0.6$ & $1.9 \pm 0.3$ & $5.2 \pm 0.7$ & $<0.6$ & $4.5 \pm 0.5$ \\
\hline${ }^{232}$ Th & $1.7 \pm 0.4$ & $2.6 \pm 0.6$ & $0.7 \pm 0.2$ & $4.3 \pm 0.7$ & $1.6 \pm 0.5$ & $3.6 \pm 0.55$ \\
\hline${ }^{40} \mathrm{~K}$ & $430 \pm 30$ & $190 \pm 10$ & $230 \pm 10$ & $330 \pm 20$ & $270 \pm 20$ & $290 \pm 20$ \\
\hline${ }^{137} \mathrm{Cs}$ & $0.13 \pm 0.05$ & $0.30 \pm 0.07$ & $<0.02$ & $0.33 \pm 0.08$ & $0.9 \pm 0.2$ & $0.17 \pm 0.05$ \\
\hline${ }^{238} \mathrm{U}$ & $<2$ & $8 \pm 2$ & $<1$ & $6 \pm 2$ & $<2$ & $7 \pm 2$ \\
\hline${ }^{235} \mathrm{U}$ & $<0.1$ & $0.4 \pm 0.1$ & $<0.05$ & $0.35 \pm 0.07$ & $<0.1$ & $0.66 \pm 0.09$ \\
\hline${ }^{210} \mathrm{~Pb}$ & $12 \pm 4$ & $110 \pm 10$ & $9 \pm 2$ & $18 \pm 5$ & $14 \pm 5$ & $65 \pm 8$ \\
\hline
\end{tabular}

Table 5. Radionuclides (Bq kg-1) in plant samples taken near and far away from landfill from TEK and TENT

\begin{tabular}{|c|c|c|c|c|}
\hline $\begin{array}{c}\text { Power } \\
\text { plant }\end{array}$ & \multicolumn{2}{|c|}{ Plant near landfill } & \multicolumn{2}{c|}{$\begin{array}{c}\text { Plant anway from } \\
\text { landfill }\end{array}$} \\
\hline $\begin{array}{c}\text { Power } \\
\text { plant }\end{array}$ & IEK & IENT & TEK & IENT \\
\hline${ }^{226} \mathrm{Ra}$ & $<0.8$ & $4.0 \pm 0.4$ & $1.8 \pm 0.3$ & $<0.5$ \\
\hline${ }^{232} \mathrm{Th}$ & $<5$ & $<0.6$ & $1.2 \pm 0.3$ & $2.2 \pm 0.4$ \\
\hline${ }^{40} \mathrm{~K}$ & $200 \pm 10$ & $360 \pm 20$ & $220 \pm 10$ & $300 \pm 20$ \\
\hline${ }^{137} \mathrm{Cs}$ & $<1$ & $0.5 \pm 0.1$ & $0.20 \pm 0.05$ & $0.18 \pm 0.06$ \\
\hline${ }^{238} \mathrm{U}$ & $<3$ & $<3$ & $<2$ & $<2$ \\
\hline${ }^{235} \mathrm{U}$ & $<0.1$ & $<0.1$ & $<0.07$ & $<0.08$ \\
\hline${ }^{210} \mathrm{Ph}$ & $37 \pm 7$ & $24 \pm 6$ & $26 \pm 4$ & $35 \pm 5$ \\
\hline
\end{tabular}

Table 6. Radionuclides ( $\left.\mathrm{Bq} \mathrm{l}^{-1}\right)$ in river water samples, drain water and overflow water from TEK and TENT

\begin{tabular}{|c|c|c|c|c|}
\hline \multirow{2}{*}{$\begin{array}{l}\text { Sample } \\
\begin{array}{c}\text { Power } \\
\text { plunt }\end{array}\end{array}$} & \multicolumn{2}{|c|}{ Finer enter sumple upstroin } & \multicolumn{2}{|c|}{ 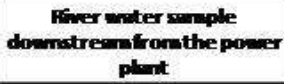 } \\
\hline & TEK & IEAT & TEK & TENT \\
\hline $\mathrm{m}_{\mathrm{ph}}$ & 0.036t0.016 & $<0.02$ & $<0.03$ & $0.011+0.003$ \\
\hline Em Th & $<0.01$ & $<0.01$ & $<0.02$ & $<0.000$ \\
\hline $7 \mathrm{~K}$ & $0.27+0.04$ & 0.0840 .02 & 0.1840.06 & $0.07 \pm 0.02$ \\
\hline${ }^{m} \mathbf{C s}$ & $<0.003$ & $<0.001$ & $<0.006$ & $<0.00018$ \\
\hline$\overline{\mathbf{y}}$ & $<0.1$ & $<0.05$ & $<0.09$ & $<0.04$ \\
\hline $\mathbf{y}$ & $<0.004$ & $<0.003$ & $<0.00\rangle$ & $<0.002$ \\
\hline Pot & $<0.1$ & $<0.08$ & $<0.04$ & $<0.06$ \\
\hline Sample & \multicolumn{2}{|c|}{ Overillower anter } & \multicolumn{2}{|c|}{ Drinenter } \\
\hline $\begin{array}{l}\text { Power } \\
\text { plont }\end{array}$ & IEK & TENT & IEK & IENT \\
\hline $\mathbf{m}_{\mathbf{H}}$ & $<0.03$ & 0.030H0.007 & $<0.03$ & 0.03240.006 \\
\hline Exth & $<0.02$ & $<0.01$ & $<0.02$ & $<0.0088$ \\
\hline 7 & 0.18џ0.05 & $0.16 \pm 0.04$ & $0.10+0.04$ & $0.18 \amalg 0.03$ \\
\hline${ }^{\mathrm{en}} \mathrm{c}$ & $<0.002$ & $<0.002$ & $<0.004$ & $<0.001$ \\
\hline$\Rightarrow$ & $<0.1$ & $<0.06$ & $<0.1$ & $<0.05$ \\
\hline कy & $<0.005$ & $<0.003$ & $<0.006$ & $<0.003$ \\
\hline $27 \mathrm{pb}$ & $<0.2$ & 0.2240 .06 & $<0.1$ & $0.17+0.06$ \\
\hline
\end{tabular}


Table 7. Gross alpha and gross beta activity (Bq l-1) in river water samples, drain water and overflow water from TEK and TENT

\begin{tabular}{|c|c|c|c|}
\hline Sample & Powrer plant & $\begin{array}{l}\text { Total a } \\
\text { activity }\end{array}$ & $\begin{array}{c}\text { Total } \beta \\
\text { activity }\end{array}$ \\
\hline \multirow{2}{*}{$\begin{array}{l}\text { River water sample } \\
\text { upstream from the } \\
\text { power plant }\end{array}$} & TEK & $<0.05$ & $0.22 \pm 0.06$ \\
\hline & TENT & $<0.04$ & $0.09 \pm 0.03$ \\
\hline \multirow{2}{*}{$\begin{array}{l}\text { River water sample } \\
\text { downstream from the } \\
\text { power plant }\end{array}$} & TEK & $<0.05$ & $0.10 \pm 0.04$ \\
\hline & TENT & $<0.05$ & $<0.08$ \\
\hline \multirow{2}{*}{ Overflow water } & TEK & $<0.13$ & $<0.22$ \\
\hline & TENT & $0.11 \pm 0.04$ & $0.26 \pm 0.09$ \\
\hline \multirow{2}{*}{ Drain water } & TEK & $<0.16$ & $0.34 \pm 0.12$ \\
\hline & TENT & $<0.1$ & $0.6 \pm 0.1$ \\
\hline
\end{tabular}

Table 8. Mean concentration of radionuclides in surrounding soil of coal fired power plants as well as in soil which were taken from areas that are not related to power plants from different countries

\begin{tabular}{|c|c|c|c|c|}
\hline \multirow{2}{*}{ Country } & \multicolumn{4}{|c|}{ Activity concentrations ( $\left.\mathrm{Bq} \mathrm{kg}^{-1}\right)$} \\
\hline & ${ }^{226} \mathrm{Ra}$ & $232 \mathrm{Th}$ & $40 \mathrm{~K}$ & $137 \mathrm{Cs}$ \\
\hline Turkey\#[22] & $28-47$ & $26-33$ & $\begin{array}{l}372- \\
646 \\
\end{array}$ & \\
\hline 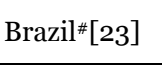 & $\begin{array}{l}39- \\
133\end{array}$ & $30-39$ & $161-233$ & \\
\hline Spain $\#[24]$ & $13-67$ & $15-68$ & $99-790$ & $\begin{array}{c}<\text { MDA- } \\
290\end{array}$ \\
\hline Serbia*$^{*}[25]$ & & $\begin{array}{l}59.4^{-} \\
71.4\end{array}$ & $\begin{array}{c}388- \\
517\end{array}$ & \\
\hline $\begin{array}{l}\text { Republic of } \\
\text { Srpska }^{\diamond}[26]\end{array}$ & 47 & 41 & 536 & 26 \\
\hline
\end{tabular}

\#Soil taken around coal fired power plants

*Soil from Lazarevac city in Serbia (city near coal fired power plant Kolubara)

$\diamond$ Soil which were taken from areas that are not related to power plant

\section{CONCLUSION}

In this paper, the results for one year of radioactivity monitoring in the vicinity of two coal fired power plants in Serbia (TEK and TENT) are presented. Monitoring included the analysis of soil, water, flying ash, slag, coal and plants. In soil, coal, plant, slag and ash samples gamma spectrometric measurements were performed. In water samples beside gamma spectroscopy, gross alpha and beta activity was determined.

Based on presented results, taking into account the continuance and depth of the investigation, we can conclude that, in terms of radioactivity, coal fired power plants in Serbia do not have significant impact on working and living environment.

Acknowledgement. The investigation was supported by The Ministry of Education, Sciences and
Technological Development of Serbia, under Project III43009.

\section{REFERENCES}

1. A. Mandal and D. Sengupta, "Radioelemental Study of Kolaghat, Thermal Power Plant, West Bengal, India: Possible Environmental Hazards," Environ. Geol., vol. 44, no. 2, pp. 180-186, June 2003

2. M.M. Janković, D.J. Todorović, J.D. Nikolić, M.M. Rajačić, G.K. Pantelić and N.B. Sarap, "Radioactivity in the Environment in Vicinity of Power Plants in Serbia: Dose Assessment," in Energy Science and Technology: Nuclear Energy, vol. 4, R. Prasad, S. Sivakumar, U.C. Sharma, J.N. Govil, Eds., Houston (TX), USA: Studium Press LLC, 2015, ch. 18, pp. 467-491

3. M. Janković, D. Todorović and J. Nikolić, "Analysis of Natural Radionuclides in Coal, Slag and Ash in CoalFired Power Plants in Serbia," J. Min. Metall. B, vol. 47, no. 2, pp. 149-155, 2011

4. M. Janković, D. Todorović, J. Nikolić, M. Rajačić, G. Pantelić and N. Sarap, "Radioactivity of Soil from CoalFired Power Plants in Serbia," in Proc. XXVII Symp. Soc. Rad. Prot., SMN, Oct. 2013, Vrnjačka Banja, Serbia, pp. 106-109

5. D. Todorović, M. Janković, J. Joksić and M. Radenković, "Transfer-Factors for Radionuclides in Coal-Fired Power Plants Environments in Serbia," in Abstr. 12th Int. Cong. Int. Rad. Prot. Assoc., Oct. 2008, Buenos Aires, Argentina, 2008, pp. 428

6. E. Charro and V. Peña, "Environmental Impact of Natural Radionuclides from a Coal-Fired Power Plant in Spain,” Rad. Prot. Dosim., vol. 153, no. 4, pp. 485-495, 2013

7. H. Aytekin and R. Baldik, "Radioactivity of Coals and Ashes from Catalagzi Coal-Fired Power Plant in Turkey," Rad. Prot. Dosim., vol. 149, no. 2, pp. 211-215, 2012

8. L. Dai, H. Wei and L. Wang, "Spatial Distribution and Risk Assessment of Radionuclides in Soils around a Coal-Fired Power Plant: A Case Study from the City of Baoji, China," Environ. Res., vol. 104, no. 2, pp. 201208, June 2007

9. H. Bem, P. Wieczorkowski and M. Budzanowski, "Evaluation of Technologically Enhanced Natural Radiation near the Coal-Fired Power Plants in the Lodz Region of Poland," J. Environ. Radioact., vol. 61, no. 2, pp. 191-201, 2002

10. D.J. Karangelos, N.P. Petropoulos, M.J. Anagnostakis, E.P. Hinis and S.E. Simopoulos, "Radiological Characteristics and Investigation of the Radioactive Equilibrium in the Ashes Produced in Lignite-Fired Power Plants," J. Environ. Radioact., vol. 77, no. 3, pp. 233-246, 2004

11. U.C. Mishra, "Environmental Impact of Coal Industry and Thermal Power Plants in India," J. Environ. Radioact., vol. 72, no. 1-2, pp. 35-40, 2004

12. C. Papastefanou, "Escaping Radioactivity from CoalFired Power Plants (CPPs) Due to Coal Burning and the Associated Hazards: a Review," J. Environ. Radioact., vol. 101, no. 3, pp. 191-200, Mar. 2010

13. A. Baeza, J.A. Corbacho, J. Guillen, A. Salas and J.C. Mora, "Analysis of the Different Source Terms of Natural Radionuclides in a River Affected by NORM (Naturally Occurring Radioactive Materials) Activities," Chemosphere, vol. 83, no. 7, pp. 933-940, May 2011

14. "Sources and effects of ionising radiation," vol. 1, UNSCEAR, UN, New York (NY), USA, 2010

15. Lj. Janković Mandić and S. Dragović, "Assessment of Terrestrial Gamma Exposure to the Population of Belgrade (Serbia)," Rad. Prot. Dosim., vol. 140, no. 4, pp. 369-377, 2010

16. S. Dragović et al., "Edaphic Factors Affecting the Vertical Distribution of Radionuclides in the Different Soil Types 
of Belgrade, Serbia,” J. Environ. Monit., vol. 14, no. 1, pp. 127-137, 2012

17. G. Pantelić, M. Eremić Savković and V. Vuletić, "Investigation of Soil in the Framework of Monitoring Radioactivity in the Environment in Serbia," in Serbian Soil Contamination by Radionuclides, and the Possibility of Remediation, M. Stojanović, Ed., Belgarde, Serbia: ITNMS, Belgrade, 2006, pp. 141-164

18. G. Dugalić et al., "Heavy Metals, Organics and Radioactivity in Soil of Western Serbia," J. Hazard. Mater., vol. 177, no. 1-3, pp. 697-702, May 2010

19. Агенција за заштиту од јонизујућих зрачења и нуклеарну сигурност Србије. (2011). Сл. гл. РС 8611 Правилник о границама садржаја радионуклида у води за пиће животним намирницама сточној храни лековима предметима опште употребе грађевинском материјалу и другој роби која се ставља у промет. [Serbian Radiation Protection and Nuclear Safety Agency. (2011). Sl. gl. RS $86 \quad 11$ Regulation on limits of radionuclide content in drinking water foodstuffs feeding stuffs drugs items of general use building materials and other goods to be placed on the market.]

20. M. Janković, D. Todorović, N. Todorović and J. Nikolov, "Natural Radionuclides in Drinking Waters in Serbia," Appl. Rad. Isot., vol. 70, no. 12, pp. 2703-2710, Dec. 2012
21. M. Janković, N. Sarap, D. Todorović and J. Joksić, "Natural and Artificial $\left({ }^{90} \mathrm{Sr}\right)$ Radionuclides in Some Carbonated Mineral Waters Used in Serbia," Nucl. Technol. Rad. Prot., vol. 28, no 3, pp. 284-292, 2013

22. U. Cevik, N. Damla and S. Nezir, "Radiological Characterization of Cayırhan Coal-Fired Power Plant in Turkey," Fuel, vol. 86, no. 16, pp. 2509-2513, Nov. 2007

23. M. Flues, V. Moraes and B.P. Mazzilli, "The Influence of a Coal-Fired Power Plant Operation on Radionuclide Concentrations in Soil," J. Environ. Radioact., vol. 63, no. 3, pp. 285-294, 2002

24. E. Charro, R. Pardo and V. Peña, "Statistical Analysis of the Spatial Distribution of Radionuclides in Soils around a Coal-Fired Power Plant in Spain," J. Environm. Radioact., vol. 124, pp. 84-92, Oct. 2013

25. S. Nenadović et al., "Vertical Distribution of Natural Radionuclides in Soil: Assessment of External Exposure of Population in Cultivated and Undisturbed Areas," Sci. Tot. Environ., vol. 429, pp. 309-316, July 2012

26. M. Janković, D. Todorović and M. Savanović, "Radioactivity Measurements in Soil Samples Collected in the Republic of Srpska," Rad. Measur., vol. 43, no. 8, pp. 1448-1452, Sep. 2008 